\title{
Acute Intestinal Anisakiasis in Spain: a Fourth-stage Anisakis simplex Larva
}

\author{
$M^{\text {a }}$ José Rosales, Carmen Mascaró/ ${ }^{+}$, Carolina Fernandez, Francisco Luque, \\ Manuel Sanchez Moreno, Luis Parras*, Antonio Cosano*, Jose Ramón Muñoz*
}

\author{
Instituto de Biotenologia, Faculdad de Ciencias, Universidad de Granada, Granada E-18071-España \\ *Hospital Ciudad de Jaén, Jaén, España
}

A case of acute intestinal anisakiasis has been reported; a nematode larva being found in the submucosa of the ileum of a woman in Jaén (Spain). The source of infection was the ingestion of raw Engraulis encrasicholus. On the basis of its morphology, the worm has been identified as a fourth-stage larva of Anisakis simplex. In Spain, this is the ninth report of human anisakiasis and also probably the first case of anisakiasis caused by a fourth-stage larva of A. simplex.

Key words: Anisakis simplex - anisakiasis - Engraulis encrasicholus - Spain

The growing popularity in western countries of eating raw or uncooked seafood has resulted in the proliferation of certain human parasitic infections. One of the most severe fish-transmitted infections is anisakiasis that results from accidental ingestion of third-stage larvae belonging to the family Anisakidae. The first case of anisakiasis in humans was described by Straub in 1955 in Holland and published in detail by Van Thiel et al. (1960). Since then, hundreds of cases have been reported throughout the world. Larvae of the genera Anisakis, Pseudoterranova (=Phocanema) and Contracaecum have been related to human infection. The larvae of Anisakis species may produce both gastric and intestinal disease, whereas Pseudoterranova infection is more associated with the invasion of the stomach wall. In some instances, after ingestion of larvae, these worms simply pass through the intestinal tract and are excreted in faeces. Extraintestinal locations as the tongue, pharynx wall, lung, lymphatic ganglia or pancreas are possible.

In Spain, since the appearance of the first human case in the scientific literature in 1991 (Arenal et al.), only seven more cases have been reported.

In the present instance, a new case of acute intestinal anisakiasis is described in which a nematode larva was found in the submucosa of the terminal ileum of a woman.

${ }^{+}$Corresponding author. Fax: +34-58-243174. E-mail: cmascaro@goliat.ugr.es

Received 6 April 1999

Accepted 16 July 1999

\section{MATERIALS AND METHODS}

We have studied a new case of acute intestinal anisakiasis in Spain. On 28 November 1998, a 46-year-old Spanish woman, lifelong resident of Jaén, was admitted to the emergency room at the Hospital Ciudad de Jaén, where her clinical, radiological and analytical report was compatible with acute appendicitis. She had had during two days acute abdominal pain, diarrhea, meteorism, selective pain palpatation in the right ileum fossa, no nausea, vomit or fever and Blumberg sign negative. The laboratory data showed leukocytosis $\left(13.780 / \mathrm{mm}^{3}\right)$, neutrophilia $(80 \%)$ and $4 \%$ of eosinophils. The rest of the red series, white and biochemical, were normal. Plain radiographs of the abdomen and an electrocardiogram were within normal limits. The clinical diagnosis was acute appendicitis. After a McBurney incision, the appendix was found to be normal, with abundant intraperitoneal exudate and inflammatory induration located in the terminal ileum, which showed a microperforation. A prophylactic appendectomy was performed, followed by a wedge resection of the indurated intestinal zone. The layers of the abdominal wall were cleaned and closed. The indurated zone was opened and, in the submucosa of the terminal ileum, a nematode of $2.5 \mathrm{~cm}$ in length was found. The neighbouring tissues were analyzed, and the caecal appendix was found with submucosal sclerolipmatosis, and the inflamed ileum was infiltrated with abundant eosinophils.

The removed larva, still moving, were placed in saline solution and fixed in $2.5 \%$ (v/v) buffered glutaraldehyde ( $\mathrm{pH}$ 7.2), and examined first under an optical microscope and later processed and examinded under a scanning electron microscope. 


\section{RESULTS AND DISCUSSION}

The body of the larva was $25 \mathrm{~mm}$ in length by 0.7 $\mathrm{mm}$ at its greatest diameter. The cuticle had continuous wide transverse striations (Fig. 1). The mouth was surrounded by three prominent lips (Fig. 2). The dorsal lip presented two double lateral papillae. The anterior muscular portion of the esophagus was 1.7 $\mathrm{mm}$ long. Neither a ventricular appendix nor an intestinal caecum could be found. The extreme posterior had no mucron, but presented a slightly prominent structure scattered with tiny spheroid projections that gave the surface a verrucose aspect (Fig. 3 ). The end of this structure had a tiny hook. On the basis of its morphological features and according to the description (Weerasooriya et al. 1986, Ishii et al. 1989), the parasite was identified as a fourth-stage larva of A. simplex.

Up to now, the cases of human parasitism by $A$. simplex described in the entire world constitute approximately $97 \%$ of all anisakiasis reported (the remaining 3\% involve the genus Pseudoterranova). Parasitism by A. physeteris (Kagei et al. 1978, Asato et al. 1991, Clavel et al. 1993), and by larvae of Contracaecum (Ishikura et al. 1993) has been confirmed in only very rare cases. The species Hysterothylacium aduncum was initially considered to be a possible etiologic agent of this disease (Petter 1969 a,b).

Anisakiasis is common in Japan, where over 2,000 cases of parasitism are registered annually, constituting $95 \%$ of the world-wide total. In Europe, the rate of infection is far less common, with only $3.5 \%$ of the total, and of these most of the cases are reported in Holland, Germany and France. While in Japan the gastric form predominates, the intestinal form is most common in Europe.

In Spain, only eight cases of anisakiasis have been published: one case of gastric anisakiasis, four cases of intestinal (two in the ileum, one in the appendix and one in the upper colon), two of ectopic anisakiasis (larvae in the abdominal cavity associated with intestinal lesions) and one of gastric pseudoterranovosis (Arenal et al. 1991, Valero et al. 1992, López-Velez et al. 1992, Clavel et al. 1993, Canut et al. 1996, Louredo et al. 1997).

The transmission of anisakiasis is intimately linked to certain culinary practices using raw, cured or pickled fish, crustaceans, squid and other molluscs. In Japan, the fish Scomber japonicus and, to a lesser extent, the squid Todarodes pacificus are the principal agents of transmission (Nagasawa 1990, 1993). In western Europe, the fish Clupea harengus appears to be the main culprit (Verhamme \& Ramboer 1988).

In Spain, third-stage larvae of A. simplex have been detected on the coasts of Galicia in 17 species
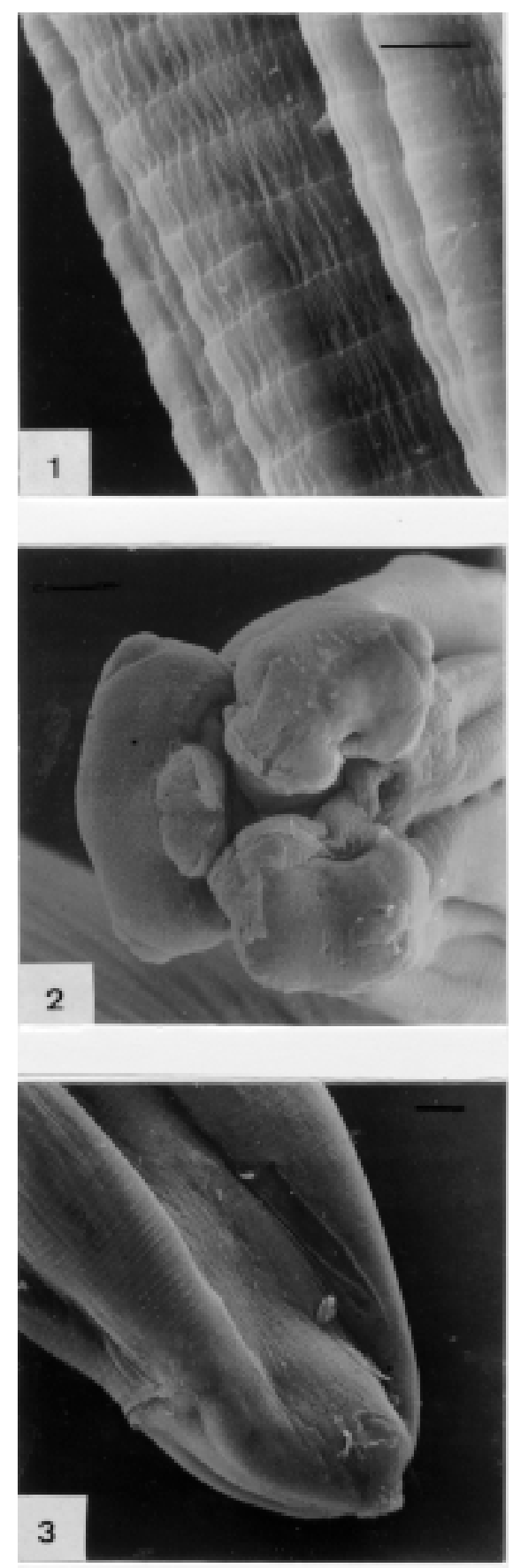

Fig. 1: pattern of continuous transverse cuticular striations on lateral side near mid-body. Bar $=5 \mathrm{~mm}$. Fig. 2: anterior part of the larva with three prominent lips. Bar $=20 \mathrm{~mm}$. Fig. 3: extreme posterior without mucron. A structure scattered with tiny speroid projections can be observed. Bar = $20 \mathrm{~mm}$.

of the 22 teleost species examined (Sanmartín et al. 1994). Six of these species registered parasite prevalence exceeding 40\%: Pollachius pollachius, Con- 
ger conger, Lophius piscatorius, Scomber scombrus, Micromesistius poutassous and Trachurus trachurus. In addition, parasitism has been discovered in three cephalopod species: Illex coindetii, Todaropsis eblanae and Todarodes sagittatus (Pascual et al. 1995). Pereira (1992) have found similar prevalence in nine fish species of the 20 examined from different Spanish ports: Serranus cabrilla, Pagellus cantabricus, Helicolenus dactylopterus, Merluccius merluccius, Phycis blennioides, T. trachurus, M. poutassous and Pollachius pollachius. Parasitism has also been observed in Engraulis encrasicholus, although with low prevalence and intensities (2.1\% and $2 \%)$. In the markets of the region Castilla-La Mancha, the fish Conger conger and T. trachurus registered prevalence exceeding 40\% (López \& Castell 1994). In the province of Granada, larvae of A. physeteris have been found in $2.4 \%$ of $M$. poutassous, $1 \%$ of Sardina pilchardus and $0.3 \%$ of T. trachurus (Valero et al. 1992). Although S. pilchardus does not appear to be among the most parasitized species, two of the eight cases of anisakiasis described up to now have been attributed to its consumption raw or with lemon (López-Velez et al. 1992). The other case in which the source of infection was identified involved cooking $M$. merluccius in a microwave oven for less than 1 min (Canut et al. 1996). Although in the rest of the cases the parasite species involved was not confirmed, the habitual ingestion of fried M. merluccius and M. poutassous could be the cause (Clavel et al. 1993). E. encrasicholus prepared in vinegar could have been the cause of the last published cases in Spain (Louredo et al. 1997). However, contrary to the situation in Japan, where anchovies (E. japonica) are abundantly infested and have been involved in many cases of parasitism (Kino et al. 1993), in Spain the species consumed (E. encrasicholus) is little parasitized (López \& Castell 1994).

The scarcity of cases reported in Spain may be due to the habit of consuming fish and cephalopods well fried or otherwise thoroughly cooked. In addition, there are difficulties in diagnosis, which can be achieved only by endoscopy (or occasionally by radiography), and these methods may give false negative results if the larvae are present only in tissues not accessible to endoscopy (small intestine, inner layers of the wall of the gastrointestinal tract, or extragastrointestinal locations), or in chronic infections which the larvae have almost completely been destroyed by the patient's immune system.

The present case involves acute intestinal anisakiasis, which typically occurs within several days after ingestion of the larvae and may cause doctors to doubt the acute appendicitis, regional ileitis or obstruction of the small intestine. In this case, the nematode perforated the mucosa, attributable to the secretion of certain hydrolytic enzymes, of which serine proteases have been isolated (metal aminopeptidases and proteases with activity similar to that of trypsine) and hyaluronidases capable of degrading macromolecules (Hotez et al. 1994). The source of infection was clearly related to the patient's habit of ingesting $E$. encrasicholus raw with olive oil. The patient did not remember having eaten any other fish raw or even marinated. Although, currently some cases in which the cause of infection is unknown, the use of microwaves to cook fish may be at fault when cooking time is less than necessary to destroy the larvae, as shown in other reports (Lane et al. 1988, Canut et al. 1996).

The larvae was identified by its morphology (Weerasooriya et al. 1986, Ishii et al. 1989), as the fourth larval stage of $A$. simplex, by the absence of a cuticular tooth, as seen by optical and electron microscopy (Fig. 2), and by the presence of a rugose protuberance in the place of the mucron (Fig. $3)$. Neither a ventricular appendix nor an intestinal caecum could be found and had wide, regularly spaced cuticular striations (Fig. 1).

The scarcity of A. simplex in E. encrasicholus in Spain (2\%), in which only third-stage larvae have been found, suggests that the fourth moult may have occurred inside the patient. That the L3 of Anisakis spp. can pass to the fourth stage in humans, parasitizing the gastrointestinal tract has been confirmed elsewhere (Kagei et al. 1978, Weerasooriya et al. 1986, Clavel et al. 1993). In experimental animals, it has been demonstrated that the parasite can pass from the L3 to the L4 stage in three days (Weerasooriya et al. 1986). In humans, according to Fujino et al. (1984), the first moult occurs three to four days after ingestion of the larva, as has been reported for a number of experimental mammalian hosts (Weerasooriya et al. 1986).

This is the ninth report of human anisakiasis in Spain, the second caused by $M$. enchasicholus and also the first case of anisakiasis in which the fourth-stage A. simplex larva has been isolated in Spain.

\section{REFERENCES}

Arenal JJ, Marcos JL, Borrego MH, Bowakin DB, Castro J, Blanco JI 1991. Anisakiasis como causa de apendicitis aguda y cuadro reumatológico: primer caso en la literatura médica. Rev Esp Enf Dig 79: 355-358.

Asato R, Wakuda M, Suiyoshi T 1991. A case of human infection with Anisakis physeteris larvae in Okinawa, Japan. Jpn J Parasitol 40: 181-183.

Canut A, Labora A, López J, Romero JA 1996. Anisakiosis gástrica aguda por cocción insuficiente en horno microondas. Med Clin 8: 317-318. 
Clavel A, Delgado B, Sanchez-Acedo C, Carbonell E, Castillo, J, Ramírez J, Quílez J, Gómez Lus R, Kagei N 1993. A live Anisakis physeteris larva found in the abdominal cavity of a woman in Zaragoza, Spain. Jpn J Parasitol 42: 445-448.

Fujino T, Ooiwa T, Ishii Y 1984. Clinical, epidemiological and morphological studies on 150 cases of acute gastric anisakiasis in Fukuoka Prefecture. Jpn J Parasitol 33: 73-92.

Hotez P, Cappello M, Hawdon J, Beckers C, Sakanari J 1994. Hyaluronidases of the gastrointestinal invasive nematodes Ancylostoma caninum and Anisakis simplex: possible functions in the pathogenesis of human zoonoses. J Inf Dis 170: 918-926.

Ishii Y, Fujino T, Weerasooriya MV 1989. Morphology of anisakine larva, p. 18-29. In H Ishikura \& K Kikuchi (eds), Gastric Anisakiasis in Japan. Epidemiology, Diagnosis, Treatment, Springer-Verlag, Tokyo.

Ishikura H, Kikuchi Y, Nagasawa K, Ooiwa T, Takamiya H, Sato N, Sugane K 1993. Anisakidae and anisakidosis, p. 43-102. In T Sun, Progress in Clinical Parasitology, Vol III, Springer-Verlag, New York.

Kagei N, Sano M, Takahashi Y, Tamura, Y, Sakamoto M 1978. A case of acute abdominal syndrome caused by Anisakis type-II larva. Jpn J Parasitol 27: 427 431.

Kino H, Watanabe K, Matsumoto K, Ueda M, Sugiura M, Suzuki H, Takai T, Tsuboi H, Sano M, Fujiu Y, Kagei N 1993. Ocurrence of anisakiais in the western part of Shizuoka prefecture, with special reference to the prevalece of anisakid infections in sardine, Engraulis japonica. Jpn J Parasitol 42: 308312.

Lane CD, Master RN, Tietbohl RH 1988. If your uneaten food moves, take it to a doctor. $J$ Am Med Assoc 260: 340-341.

López R, Castell J 1994. Estudio de la tasa de parasitación por nematodos del género Anisakis en el pescado fresco de venta más frecuente en Castilla La Mancha. Alimentaria 31:37-42.

López-Velez R, García A, Barros C, Manzarbeitia F, Oñate JM 1992. Anisakiasis en España. Descripción de 3 casos. Enf Inf Microb Clin 10: 158-161.

Louredo A, Acedo de la Rosa F, Offibas de Paz V, Sanz E, Quiros BL, Goyanes M 1997. Anisakidosis del colon como causa de abdomen agudo. Rev Esp de Enf Dig 89: 403-406.

Nagasawa K 1990. Anisakis larvae in intermediate and paratenic hosts in Japan, p. 23-29. In H Ishikura H
K Kikuchr (eds), Intestinal Anisakiasis in Japan. Infected Fish, Sero-immunological Diagnosis, and Prevention, Springer-Verlag, Tokyo.

Nagasawa K 1993. Review of human pathogenic parasites in the Japanese common squid (Todarodes pacificus), p. 293-212. In T Okutani, RK O’Dor \& T Kubodera (eds), Recent Advances in Fisheries Biology, Tokai University Press, Tokyo.

Pascual S, Gestal C, Soto M, Rodríguez H, Estévez J, Arias C 1995. Identificación electroforética de Anisakis simplex (Rudolphi, 1809 det. Krabbe, 1878), nematodos parásitos de ommastréfidos (Mollusca, Cephalopoda) en el sureste noratlántico, p. 55. In IV Congreso Ibérico de Parasitología, Julio, Santiago de Compostela, Spain.

Pereira JM 1992. Algunos aspectos de la epidemiología y prevención de la anisakiosis, p. 64. Junta de Castillo y León. Consejería de Sanidad y Bienestar social, Dirección General de Salud Pública.

Petter AJ 1969a. Enquête sur les nématodes des sardines pêchées dans la région nantaise. Rapport possible avec les granulomes éosinophiles observés chez l'homme dans la région. Ann Parasitol Hum et Comp 44: 25-35.

Petter AJ 1969b. Enquête sur les nématodes des poissons de la région nantaise. Identification des larves d'ascarides parasitant les sardines (en rapport avec les granulomes éosinophiles observés chez l'homme dans la région). Ann Parasitol Hum et Comp 44: 559579.

Sanmartín ML, Iglesias R, Santamarina MT, Leiro J, Ubeira FM 1994. Nematodos Parásitos en Peces de las Costas Gallegas, Díaz Santos, Madrid, 80 pp.

Valero A, Gutiérrez J, Pérez R, Sanz-Dominguez J, Geraldia M, García-Herruzo J, García-Martos P, Adroher FJ 1992. Descripción de un caso de anisakiosis humana, p. 69. In IX Reunión Científica de la Asociación de Parasitólogos Españoles, October, León, Spain.

Van Thiel PH, Kuipers FC, Roskam TH 1960. A nematode parasitic to herring, causing acute abdominal sydromes in man. Trop Geograph Med 12: 97-113.

Verhamme MAM, Ramboer CHR 1988. Anisakiasis caused by herring in vinegar: a little known medical problem. Gut 29: 843-847.

Weerasooriya MV, Fujino T, Ishii Y, Kagei N 1986. The value of external morphology in the identification of larval anisakid nematodes: a scanning electron microscope study. Zeitsch für Parasiten 72: 765-778. 